\title{
COMPARISON OF PROTEINS, LETHALITY AND IMMUNOGENIC COMPOUNDS OF Androctonus crassicauda (OLIVIER, 1807) (SCORPIONES: BUTHIDAE) VENOM OBTAINED BY DIFFERENT METHODS
}

\author{
OZKAN O. (1, 2), KAR S. (2), GÜVEN E. (2) ERGUN G. (3)
}

(1) Refik Saydam Hygiene Center, Ankara, Turkey; (2) Department of Entomology, Faculty of Veterinary Medicine, Ankara, Turkey; (3) Department of Statistics, Faculty of Sciences, Hacettepe University, Ankara, Turkey.

\begin{abstract}
Scorpions are venomous arthropods of the class Arachnida and are considered relatives of spiders, ticks and mites. There are approximately 1,500 species of scorpions worldwide, which are characterized by an elongated body and a segmented tail that ends in a venomous stinger. No specific treatment is available for scorpion envenomation, except for the use of antivenom. The current study aimed at comparing protein content and lethality of Androctonus crassicauda venom extracted by two different methods (electric stimulation and maceration of telsons). The $\mathrm{LD}_{50}$ calculated by probit analysis was $1.1 \mathrm{mg} / \mathrm{kg}$ for venom obtained by electric stimulation and $39.19 \mathrm{mg} / \mathrm{kg}$ for venom obtained by maceration of telsons. In the electrophoretic analysis, protein bands of the venom sample obtained by electric stimulation were between 12 and 53kDa (total: five bands), and those of venom extracted by maceration appeared as multiple protein bands, relative to the other venom sample. Low-molecular-weight proteins, revealed by western blotting, played an important immunogenic role in the production of antivenom. Lethality and protein levels varied according to the extraction method; venom obtained by the maceration technique showed lower toxicity than that obtained by electric stimulation.
\end{abstract}

KEY WORDS: scorpion venoms, Androctonus crassicauda, gland maceration, electric stimulation, immunogenicity, lethality.

CONFLICTS OF INTEREST: There is no conflict.

\section{CORRESPONDENCE TO:}

OZCAN OZKAN, Refik Saydam Hygiene Center, 06100, Ankara, Turkey. Phone: 00 9031245823 72. Email: ozcanozkan_62@hotmail.com. 
O. Ozkan et al. COMPARISON OF PROTEINS, LETHALITY AND IMMUNOGENIC COMPOUNDS OF Androctonus crassicauda (OLIVIER, 1807) (SCORPIONES: BUTHIDAE) VENOM OBTAINED BY DIFFERENT METHODS. J. Venom. Anim. Toxins incl. Trop. Dis., 2007, 13, 4, p. 845

\section{INTRODUCTION}

The three most important orders of Arachnida are Araneae (spiders), Scorpiones (scorpions) and Acari (ticks and mites) (10, 19, 25). Scorpions are terrestrial arachnids that are easily recognized by their characteristic elongated body and segmented tail ending in a bulbous sac and in a stinger (telson); there are approximately 1,500 scorpion species worldwide $(4,19,24,26)$. Scorpion venom, which has lethal and paralytic effects, is a secretion composed of water, salts and simple, low-molecular-weight proteins $(5,10,23)$. It is a unique defense and feeding weapon. Scorpions also employ this valuable tool, in several sophisticated ways, for subduing prey, deterring predators, probably during mating, and most of the times for protection against humans $(2,4,9,12)$. Thus, scorpion envenomation still remains a major health problem in many tropical and subtropical countries $(2,4,18,22,30)$.

Antivenom is still widely used in the treatment of envenomation as there are no vaccines or other effective agents available against animal venoms (31). Hence, representatives of 21 laboratories around the world, both public and private, have presented the methodologies used for producing antivenom (30). It is clear that availability of effective antivenom constitutes the cornerstone of envenomation treatment and requires the use of scorpion venom, which can be obtained by different methods such as manual extraction, electric stimulation and maceration (4, 17, 23, 24, 30). In Turkey, scorpion venom has been obtained by maceration of telsons since 1942 at Refik Saydam Hygiene Center (RSHC), Ankara, Turkey (20).

In the current work, scorpion venom samples obtained by two different methods were compared as to protein content and lethality and evaluated in order to verify (i) which method was the best for immunization, (ii) which compounds present in these venom samples have a relevant role in the production of antivenom, and (iii) which of these compounds can be considered immunogens.

\section{MATERIALS AND METHODS}

\section{Animals}

Scorpions: Androctonus crassicauda (Figure 1) specimens were collected in Sanliurfa and Mardin provinces (Southeastern Anatolia), Turkey. They received water daily and were fed with crickets or cockroaches after every milking. 
O. Ozkan et al. COMPARISON OF PROTEINS, LETHALITY AND IMMUNOGENIC COMPOUNDS OF Androctonus crassicauda (OLIVIER, 1807) (SCORPIONES: BUTHIDAE) VENOM OBTAINED BY DIFFERENT METHODS. J. Venom. Anim. Toxins incl. Trop. Dis., 2007, 13, 4, p. 846

Mice: Male Swiss albino mice $(20 \pm 2 \mathrm{~g})$ were used in all experiments. They were bred and maintained at the Department for Laboratory Animals of RSHC. Mice were kept under room temperature and $60 \pm 10 \%$ humidity and fed with commercial rodent food pellets ad libitum throughout the experiment.

\section{Venom samples}

Electric stimulation method: Venom from mature scorpions was obtained by electric stimulation of their telsons, as previously described (24). It was mixed with sterile double distilled water and centrifuged at $10000 \mathrm{~g}$ for $15 \mathrm{~min}$ at $4^{\circ} \mathrm{C}$. Supernatant was stored at $-20^{\circ} \mathrm{C}$ in the dark until use.

Maceration method: Three hundred and seventy-six telsons (Figure 2) of $A$. crassicauda were used. Venom solution was prepared by macerating telsons as previously described $(23,24)$. All telsons were weighed by using an electronic balance with sensitivity of $0.001 \mathrm{mg}$. Briefly, telsons were removed from dead scorpions at the point of their articulation with the last caudal segment. Then, they were ground to a fine powder which was dissolved in physiologic saline solution (PSS; $0.9 \% \mathrm{w} / \mathrm{v} \mathrm{NaCl}$ ) and kept at $4^{\circ} \mathrm{C}$ for $72 \mathrm{~h}$. The venom solution was centrifuged at $10000 \mathrm{~g}$ for $10 \mathrm{~min}$ at $4^{\circ} \mathrm{C}$. Supernatant was removed and immediately lyophilized and stored at $-20^{\circ} \mathrm{C}$ until use.

\section{Antivenom}

The used antivenom was produced at RSHC by maceration of $A$. crassicauda telsons followed by administration to horses.

\section{Protein assay}

Protein content of the venom samples was determined by reading absorbance at $280 \mathrm{~nm}$ and expressed as $\mathrm{mg}$ protein/ml $(16,29)$.

\section{Lethality assay}

The median lethal dose $\left(L_{50}\right)$ for $A$. crassicauda venom extracted by both electric stimulation and maceration was calculated in mice. The used doses covered the full range of mortality from 0 to $100 \%$. Venom was subcutaneously injected, at increasing doses, into groups of at least five mice each. An equivalent volume of PSS was 
O. Ozkan et al. COMPARISON OF PROTEINS, LETHALITY AND IMMUNOGENIC COMPOUNDS OF Androctonus crassicauda (OLIVIER, 1807) (SCORPIONES: BUTHIDAE) VENOM OBTAINED BY DIFFERENT METHODS. J. Venom. Anim. Toxins incl. Trop. Dis., 2007, 13, 4, p. 847

injected into a group of five mice as negative control for each test. Following treatment with venom solution, the animals were monitored for $24 \mathrm{~h}$ and $L_{50}$ was then calculated using the probit method (7).

\section{Sodium dodecyl sulfate polyacrylamide gel electrophoresis (SDS-PAGE)}

SDS-PAGE $(7.5 \% \mathrm{gel})$ analyses of both venom samples and their protein bands were carried out according to Laemmli (14). Proteins were stained with $0.1 \%$ Coomassie Blue R-250 Silver (6). Molecular mass standard (Sigma, S8445) were run in parallel in order to calculate the molecular weights of proteins. Then, gel was photographed and the molecular weights were calculated using Molecular Imaging Software (MIS, Kodak).

\section{Western blotting}

Venom samples were separated on polyacrylamide gel, electrophoretically transferred to nitrocellulose membrane (NCM) and divided into two sections. The membranes were incubated in blocking buffer - $5 \%$ powdered milk (PM) in TrisBuffered Saline Tween-20 (TBST; 0.1\% Tween 20, 150 mM NaCl, 10 mM Tris-Cl; pH 7.4) for $60 \mathrm{~min}$.

Strips of the membranes were washed 3 times with TBST and exposed to diluted antivenom (1:1000) for $1 \mathrm{~h}$. Then, they were again washed three times with TBST and incubated with horseradish peroxidase-conjugated anti-horse antibody (1:5000) for $60 \mathrm{~min}$. Membranes were washed with TBST for 10min and antigens were visualized using 3,3'-diaminobenzidine (DAB; Sigma, SD0426) substrate; after development of the bands, reaction was stopped with PBS.

\section{RESULTS}

\section{Lethality assay}

All 376 telsons weighed $5.32 \mathrm{~g}$ and a single telson, 14.14mg. $L_{50}$ was $39.46 \mu \mathrm{l} / \mathrm{mouse}(1.1 \mathrm{mg} / \mathrm{kg} ; 95 \%$ confidence interval-Cl: 31.16-46.92) for venom obtained by electric stimulation and $106.79 \mu \mathrm{l} / \mathrm{mouse}(39.19 \mathrm{mg} / \mathrm{kg} ; 95 \% \mathrm{Cl}$ : $84.37-$ 132.15) for venom obtained by maceration of telsons. Mice showed the same envenomation symptoms after sc injection of both venom samples (Table 1). 
O. Ozkan et al. COMPARISON OF PROTEINS, LETHALITY AND IMMUNOGENIC COMPOUNDS OF Androctonus crassicauda (OLIVIER, 1807) (SCORPIONES: BUTHIDAE) VENOM OBTAINED BY DIFFERENT METHODS. J. Venom. Anim. Toxins incl. Trop. Dis., 2007, 13, 4, p. 848

\section{SDS-PAGE and Western Blotting}

Protein content of venom obtained by maceration of telsons was $7.34 \mathrm{mg} / \mathrm{ml}$ and that of venom obtained by electric stimulation was $0.561 \mathrm{mg} / \mathrm{ml}$. In the electrophoretic analysis, the venom sample obtained by electric stimulation showed protein bands between 12 and 53kDa (Figure 3; Lane A), and the venom sample obtained by maceration of telsons showed multiple protein bands (compared with the profile of the other venom sample) mostly between 12 and 162kDa (Figure 3, Lane B). For venom obtained by electric stimulation, five protein bands were observed, whereas for venom obtained by maceration, nine bands were noticed, and when compared, they showed only three similar protein bands $-12 \mathrm{kDa}, 29 \mathrm{kDa}$, and $35 \mathrm{kDa}$ (Figure 3). Androctonus crassicauda antivenom strongly reacted with the venom obtained by the maceration method. Western blotting indicated $36,53,58$ and $74 \mathrm{kDa}$ proteins as immunogens, contrasting to the results of the electrophoretic analysis. Specific antibody reacted with venom obtained by electric stimulation (Figure 4) for 36, 42, 53, 58, 74, 86, 135 and 150kDa proteins, which were considered immunogens. Comparison of western blotting profiles of both venom samples showed proteins with similar molecular weights $(36,53$ and $58 \mathrm{kDa})$.

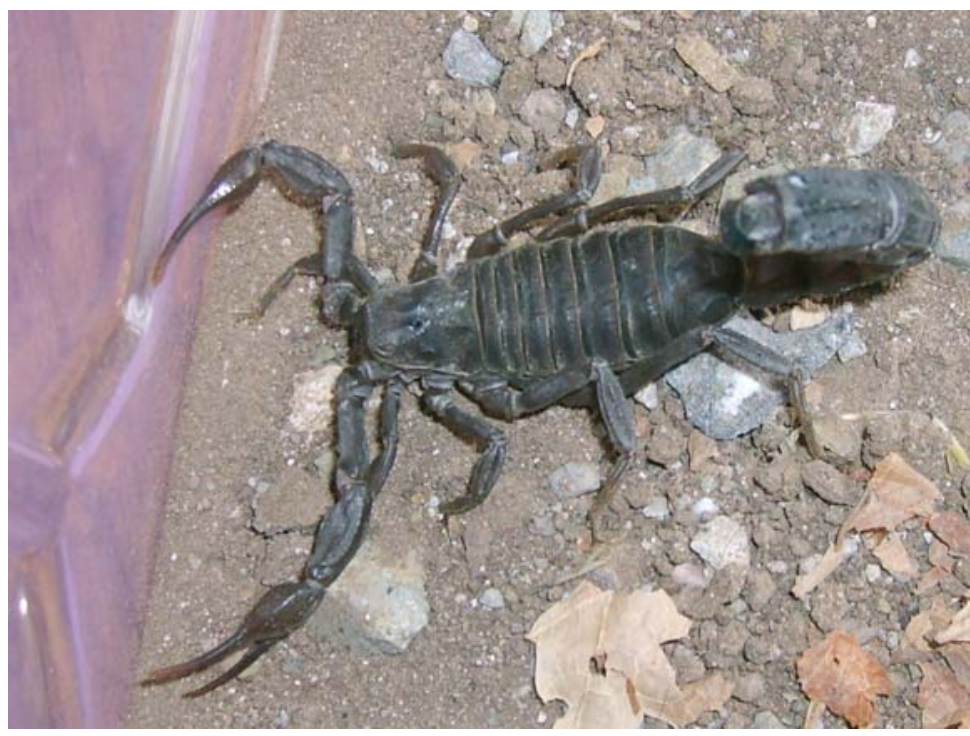

Figure 1. Androctonus crassicauda from the southeastern region of Anatolia, Turkey. 
O. Ozkan et al. COMPARISON OF PROTEINS, LETHALITY AND IMMUNOGENIC COMPOUNDS OF Androctonus crassicauda (OLIVIER, 1807) (SCORPIONES: BUTHIDAE) VENOM OBTAINED BY DIFFERENT METHODS. J. Venom. Anim. Toxins incl. Trop. Dis., 2007, 13, 4, p. 849

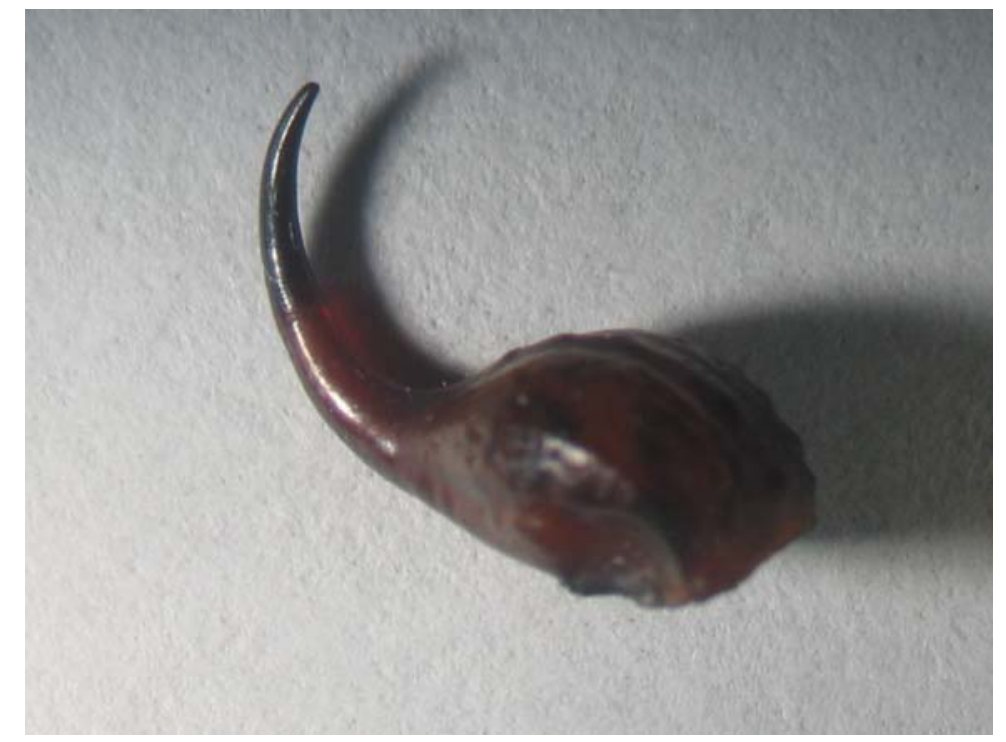

Figure 2. Telson removed from a dead Androctonus crassicauda at the point of its articulation with the last caudal segment.

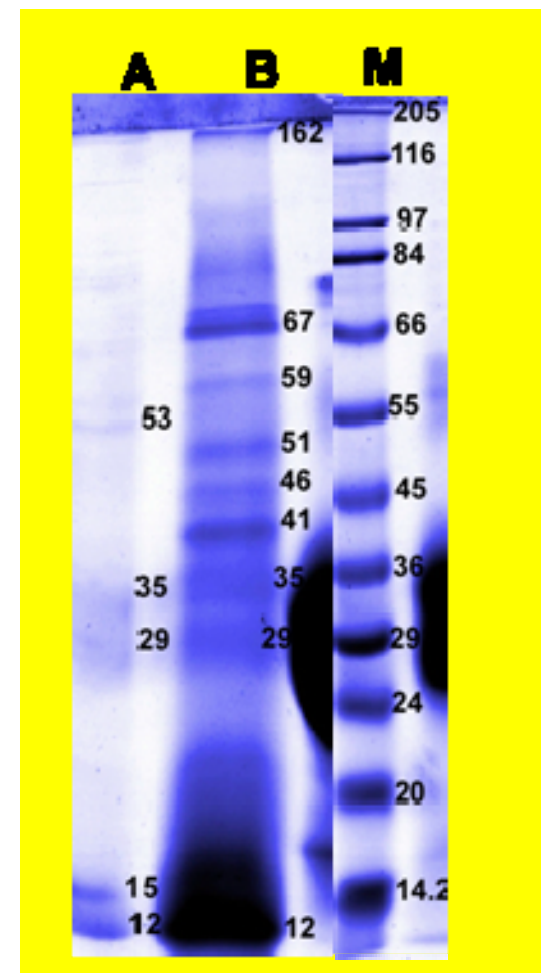

Figure 3. SDS-gel electrophoresis of Androctonus crassicauda venom. Lane A: venom obtained by electric stimulation; Lane $B$ : venom obtained by maceration of telsons; Lane M: molecular weight markers - 205kDa (Myosin), 116kDa ( $\beta$ Galactosidase), 66kDa (Albumin), 45kDa (Ovalbumin), and 14.5kDa ( $\alpha$-Lactalbumin). 
O. Ozkan et al. COMPARISON OF PROTEINS, LETHALITY AND IMMUNOGENIC COMPOUNDS OF Androctonus crassicauda (OLIVIER, 1807) (SCORPIONES: BUTHIDAE) VENOM OBTAINED BY DIFFERENT METHODS. J. Venom. Anim. Toxins incl. Trop. Dis., 2007, 13, 4, p. 850

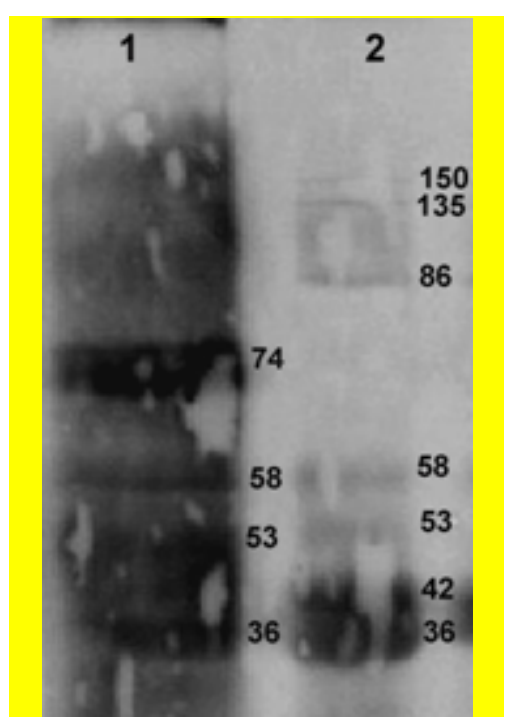

Figure 4. Western blotting using Androctonus crassicauda venom (1:1000). Lane 1: venom obtained by maceration of telsons; Lane 2: venom obtained by electric stimulation. Venom samples were separated and transferred to nitrocellulose membranes. Bands were detected using antivenom.

Table 1. Median lethal dose $\left(L D_{50}\right)$ of Androctonus crassicauda venom obtained by two different methods (maceration and electric stimulation) and subcutaneously injected into mice. Similar symptoms were observed in mice during $L D_{50}$ determination.

\begin{tabular}{c|c|c||c|c|c}
\hline \hline \multicolumn{3}{c||}{ Maceration } & \multicolumn{3}{c}{ Electric stimulation } \\
\hline \hline $\begin{array}{c}\text { Venom } \\
\text { ( } \boldsymbol{\mu g} / \text { mouse) }\end{array}$ & $\begin{array}{c}\text { Time } \\
(\mathbf{h})\end{array}$ & $\begin{array}{c}\text { Mice } \\
\text { (Death/total) }\end{array}$ & $\begin{array}{c}\text { Venom } \\
(\boldsymbol{\mu g} / \text { mouse) }\end{array}$ & $\begin{array}{c}\text { Time } \\
(\mathbf{h})\end{array}$ & $\begin{array}{c}\text { Mice } \\
\text { (Death/total) }\end{array}$ \\
\hline 376 & 24 & $0 / 5$ & 10 & 24 & $0 / 5$ \\
611 & 24 & $1 / 5$ & 15 & 24 & $1 / 5$ \\
815 & 24 & $2 / 5$ & 20 & 24 & $2 / 5$ \\
993 & 24 & $5 / 5$ & 25 & 24 & $4 / 5$ \\
& & & 30 & 24 & $4 / 5$ \\
& & & 35 & 24 & $5 / 5$ \\
\hline
\end{tabular}

\section{DISCUSSION}

Scorpion venom contains short neurotoxin polypeptides consisting of simple, lowmolecular-weight proteins which have lethal and paralytic effects (10). Approximately 100,000 distinct peptides are estimated to be present in scorpion venom but only a limited number of these peptides have been described so far (28). The lethal fraction 
O. Ozkan et al. COMPARISON OF PROTEINS, LETHALITY AND IMMUNOGENIC COMPOUNDS OF Androctonus crassicauda (OLIVIER, 1807) (SCORPIONES: BUTHIDAE) VENOM OBTAINED BY DIFFERENT METHODS. J. Venom. Anim. Toxins incl. Trop. Dis., 2007, 13, 4, p. 851

of venom samples from different scorpion species has similar effects on the autonomic nervous system (3).

Venom toxicity varies with several factors such as genus, species, age, physiology, feeding state and region of the scorpion $(13,23,27,30)$. This was reiterated by Krifi et al. (13), who reported difficulties in standardizing venom quality. Therefore, these parameters must be specified for any venom $L_{50}$ or antivenom potency values reported. Also, such venom variability must be taken into consideration in the development of an antivenom product, which must neutralize the toxic effects of venom samples from all scorpions within a species (30). Venom toxicity varies among species or among members of one species that are from different regions (8, $13,21)$. Ismail $(11)$ reported that $L D_{50}$ of Leiurus quinquestriatus venom varies from $0.23 \mathrm{mg} / \mathrm{kg}$ to $6.5 \mathrm{mg} / \mathrm{kg}$.

The $\mathrm{LD}_{50}$ of scorpion venom can vary even if the venom was extracted by using one single method. For instance, Ismail et al. (12) found that the $\mathrm{LD}_{50}$ of $A$. crassicauda venom obtained by electric stimulation was $0.64 \mathrm{mg} / \mathrm{kg}$, whereas Latoxan Laboratory reported a $L D_{50}$ of $0.87 \mathrm{mg} / \mathrm{kg}$ for $A$. crassicauda venom obtained by the same method. However, Altinkurt and Altan (1) reported that the $L_{50}$ of $A$. crassicauda venom, from Sanliurfa region, was $11.5 \mathrm{mg} / \mathrm{kg}$ by the maceration method. Ozkan and Filazi (24) stated that toxicity of milked venom is eight times higher than that of venom obtained by maceration of telsons. Similarly, Latifi and Tabatabai (15) reported that $A$. crassicauda venom extracted by electric stimulation was more lethal than that obtained by maceration of telsons. However, after administration of both venom samples, mice showed symptoms such as hyperactivity, excitability, jumping, humpback, tachypnea, dyspnea, bleeding from the nose and eyes, lacrimation, hypersalivation, weakness, paralysis and coma, resulting in death.

Latifi and Tabatabai (15) reported that the mean amount of venom obtained by electric stimulation was $0.3 \mathrm{mg}$ per scorpion ( $A$. crassicauda), whereas by maceration of the telsons, $0.5 \mathrm{mg}$ per scorpion was obtained. This variation was due to different scorpion size, age, sex and collection site. Ozkan et al. (23) reported that venom samples extracted by maceration showed different toxicities according to the weight and size of the telsons. The authors explained that this difference was caused by the different maturity stages of the animals and thus venom toxicity was related to the scorpion size (23). Differences among scorpion venom toxicities could be due to 
O. Ozkan et al. COMPARISON OF PROTEINS, LETHALITY AND IMMUNOGENIC COMPOUNDS OF Androctonus crassicauda (OLIVIER, 1807) (SCORPIONES: BUTHIDAE) VENOM OBTAINED BY DIFFERENT METHODS. J. Venom. Anim. Toxins incl. Trop. Dis., 2007, 13, 4, p. 852

transporting conditions, drying method, storage, and period of use of telsons. Also, these differences can be attributed to the fact that the venom extracted by maceration contains undesirable substances such as epithelium cells of venom gland. In the current study, $L_{50}$, calculated by probit analysis, was $1.1 \mathrm{mg} / \mathrm{kg}$ for venom obtained by electric stimulation and $39.19 \mathrm{mg} / \mathrm{kg}$ for venom obtained by maceration of telsons.

On the other hand, venom is a complex mixture of antigens, and not all but some of these antigens are important for the production of neutralizing antibodies $(5,17)$. Thus, identification of immunogenic proteins may allow the use of substances more clearly defined as immunogens in the development of more efficient antivenom ( 9 , 17).

Antivenom has an important role in the treatment of scorpionism cases $(2,18)$. It is produced from venom samples obtained by scorpions using different methods, which are very important factors for the production of more efficient antivenoms. CalderonAranda et al. (5) immunized animals by using macerated telsons, milked venom, and venom fractions of Centruroides noxius scorpion. The authors stated that the best antigen preparation for immunization is highly-purified venom fraction, followed by milked venom, but venom obtained by telson maceration is less efficient (5). In the current study, immunogenic proteins and lethality of $A$. crassicauda venom obtained by different methods were compared, important components to be neutralized by specific antibodies were investigated, and immunogenic proteins in the venom leading to immunological reactions were identified. According to SDS-PAGE analysis, venom obtained by telson maceration showed nine protein bands, whereas venom obtained by electric stimulation showed only five bands. Comparison of protein bands from both venom samples indicated similarity between low-molecularweight proteins, which were considered immunogenic according to western blotting, where these proteins were recognized by specific antivenom.

The present results indicated that low-molecular-weight proteins played an important immunogenic role in the production of antivenom. Lethality and protein patterns showed variability according to the used method. Toxicity of venom obtained by maceration was lower than that of venom obtained by electric stimulation. Therefore, variation in toxicity depends on the employed extraction method which is probably important for the venom lethality. Venom obtained by maceration showed lower 
O. Ozkan et al. COMPARISON OF PROTEINS, LETHALITY AND IMMUNOGENIC COMPOUNDS OF Androctonus crassicauda (OLIVIER, 1807) (SCORPIONES: BUTHIDAE) VENOM OBTAINED BY DIFFERENT METHODS. J. Venom. Anim. Toxins incl. Trop. Dis., 2007, 13, 4, p. 853

toxicity as, during collection, scorpions might have used their venom for protection; in addition, physiological and feeding states of the animals change during the collection period.

Electric stimulation is more efficient than maceration in extracting venom for scorpion antivenom production as scorpions can be constantly used to produce venom whereas maceration requires telsons from dead scorpions. The electric stimulation procedure is also more simple and economical than the maceration procedure; therefore, it could be adopted in antivenom production. Extraction of venom from living scorpions is also an important factor in protecting scorpion fauna.

Antivenom production is generally based on the application of purified venom or antigens on horses, which prevents undesirable substances (epithelium cells of venom gland, etc) and leads to high and specific antibody (only specific proteins) production. This easily provides effective immunological protection against the venom and requires injection of low doses of immunoglobulin into the patients, also protecting them from possible serum sickness.

\section{ACKNOWLEDGEMENTS}

We wish to thank Karina Chamma for her valuable comments on this manuscript.

\section{REFERENCES}

1 ALTINKURT O., ALTAN M. Pharmacological effects of the scorpion (Androctonus crassicauda) venom from Urfa environment on laboratory animals and the antagonistic effects of streptomycin to most of these effects. J. Fac. Pharm. Ankara, 1980, 10, 41-61.

2 BALOZET L. Scorpionism in the old world. In: BÜCHERL W., BUCKLEY E. Eds. Venomous animals and their venoms. Venomous invertebrates. New York: Academic Press, 1971, 3, 349-71.

3 BAWASKAR HS. Management of severe scorpion sting at rural settings: what is the role of scorpion antivenom? J. Venom. Anim. Toxins incl. Trop. Dis., 2005, 11, 37.

4 BÜCHERL W. Classification, biology and venom extraction of scorpion In: BÜCHERL W., BUCKLEY E. Eds. Venomous Animals and their Venoms. Venomous Invertebrates. New York: Academic Press, 1971, 3, 317-47. 
O. Ozkan et al. COMPARISON OF PROTEINS, LETHALITY AND IMMUNOGENIC COMPOUNDS OF Androctonus crassicauda (OLIVIER, 1807) (SCORPIONES: BUTHIDAE) VENOM OBTAINED BY DIFFERENT METHODS. J. Venom. Anim. Toxins incl. Trop. Dis., 2007, 13, 4, p. 854

5 CALDERON-ARANDA ES., HOZBOR D., POSSANI LD. Neutralizing capacity of murine sera induced by different antigens of scorpion venom. Toxicon, 1993, 31, 327-37.

6 CANDIANO G., BRUSCHI M., MUSANTE L., SANTUCCI L., GHIGGERI GM., CARNEMOLLA B., ORECCHIA P., ZARDI L., RIGHETTI PG. Blue silver: a very sensitive colloidal Coomassie G-250 staining for proteome analysis. Electrophoresis, 2004, 25, 1327-33.

7 FINNEY DJ. Probit analysis. 3.ed. London: Cambridge University Press, 1971: $331 \mathrm{p}$.

8 HASSAN F. Production of scorpion antivenom. In: TU AT. Ed. Handbook of Natural Toxins. New York: Marcel Dekker, 1984, 2, 577-605.

9 INCEOGLU B., LANGO J., RABINOVICH A., WHETSTONE P., HAMMOCK BD. The neutralizing effect of a polyclonal antibody raised against the $\mathrm{N}$-terminal eighteen-aminoacid residues of birtoxin towards the whole venom of Parabuthus transvaalicus. Toxicon, 2006, 47, 144-9.

10 ISBISTER GK., GRAUDINS A., WHITE J., WARRELL D. Antivenom treatment in Arachnidism. J. Toxicol. Clin. Toxicol., 2003, 41, 291-300.

11 ISMAIL M. Serotherapy of the scorpion envenoming syndrome is irrationally convicted without trail. Toxicon, 1993, 31, 1077-88.

12 ISMAIL M., ABD-ELSALAM MA., AL-AHAIDIB MS. Androctonus crassicauda (OLIVIER, 1807), a dangerous and unduly neglected scorpion-I. Pharmacological and clinical studies. Toxicon, 1994, 32, 1599-618.

13 KRIFI MN., MARRAKCHI N., EL AYEB M., DELLAGI K. Effect of some variables on the in vivo determination of scorpion and viper venom toxicities. Biologicals, 1998, 26, 277-88.

14 LAEMMLI K. Cleavage of structural proteins during the assembly of the head of bacteriophage T4. Nature, 1970, 227, 680-5.

15 LATIFI M., TABATABAI M. Immunological studies on Iranian scorpion venom and antivenom. Toxicon, 1979, 17, 617-20.

16 LAYNE E. Spectrophotometric and turbidimetric methods for measuring proteins. Methods Enzymol., 1957, 3, 447-55. 
O. Ozkan et al. COMPARISON OF PROTEINS, LETHALITY AND IMMUNOGENIC COMPOUNDS OF Androctonus crassicauda (OLIVIER, 1807) (SCORPIONES: BUTHIDAE) VENOM OBTAINED BY DIFFERENT METHODS. J. Venom. Anim. Toxins incl. Trop. Dis., 2007, 13, 4, p. 855

17 MARIA WS., VELARDE DT., ALVARENGA LM., NGUYEN C., VILLARD S., GRANIER C., CHAVEZ-OLORTEGUI C. Localization of epitopes in the toxins of Tityus serrulatus scorpions and neutralizing potential of therapeutic antivenoms. Toxicon, 2005, 46, 210-7.

18 MEDDEB-MOUELHI F., BOUHAOUALA-ZAHAR B., BENLASFAR Z., HAMMADI M., MEJRI T., MOSLAH M., KAROUI H., KHORCHANI T., MOHAMED EA. Immunized camel sera and derived immunoglobulin subclasses neutralizing Androctonus australis hector scorpion toxins. Toxicon, 2003, 42, 785-91.

19 MULLEN GR., STOCKWELL SA. Scorpions (Scorpiones). In: MULLEN G., DURDEN G. Eds. Medical and Veterinary Entomology. Amsterdam: Academic Press, 2002, 20, 411-23.

20 OZKAN O., ADIGUZEL S., ATES C., BOZYIGIT I., FILAZI A. Optimization of antiscorpion venom production. J. Venom. Anim. Toxins incl. Trop. Dis., 2006, 12, 390-9.

21 OZKAN O., ADIGUZEL S., KAR S. Parametric values of Androctonus crassicauda (OLIVER, 1807) (Scorpiones: Buthidae) from Turkey. J. Venom. Anim. Toxins incl. Trop. Dis., 2006, 12, 549-59.

22 OZKAN O., ADIGUZEL S., YAKISTIRAN S., CESARETLI Y., ORMAN M., KARAER Z. Androctonus crassicauda (OLIVIER, 1807) scorpionism in the Sanliurfa region of Turkey. Acta Parasitol. Turcica, 2006, 30, 239-45.

23 OZKAN O., ADIGUZEL S., YAKISTIRAN S., FILAZI A. Study of the relationship between Androctonus crassicauda (OLIVIER, 1807; Scorpiones, Buthidae) venom toxicity and telson size, weight and storing condition. J. Venom. Anim. Toxins incl. Trop. Dis., 2006, 12, 297-309.

24 OZKAN O., FILAZI A. The determination of acute lethal dose-50 (LD 50 ) levels of venom in mice, obtained by different methods from scorpions Androctonus crassicauda (OLIVER, 1807). Acta Parasitol. Turcica, 2004, 28, 50-3.

25 OZKAN O., KARAER Z. Body structures of scorpions. Acta Parasitol. Turcica, 2004, 28, 54-8.

26 OZKAN O., KARAER Z. Scorpions in Turkey. J. Turkish Hyg. Exp. Biol., 2004, 61, 50-3. 
O. Ozkan et al. COMPARISON OF PROTEINS, LETHALITY AND IMMUNOGENIC COMPOUNDS OF Androctonus crassicauda (OLIVIER, 1807) (SCORPIONES: BUTHIDAE) VENOM OBTAINED BY DIFFERENT METHODS. J. Venom. Anim. Toxins incl. Trop. Dis., 2007, 13, 4, p. 856

27 PADILLA A., GOVEZENSKY T., POSSANI L.D., LARRALDE C. Experimental envenoming of mice with venom the scorpion Centruroides limpidus: differences in mortality and symptoms with and without antibody therapy relating to differences in age, sex and strain of mouse. Toxicon, 2003, 41, 959-65.

28 POSSANI LD., BECERRIL B., DELEPIERRE M., TYTGAT J. Scorpion toxins specific for $\mathrm{Na}^{+}$-channels. Eur. J. Biochem., 1999, 264, 287-300.

29 STOSCHECK CM. Quantitation of protein. Methods Enzymol., 1990, 182, 50-69. 30 THEAKSTON RD., WARRELL DA., GRIFFITHS E. Report of a WHO workshop on the standardization and control of antivenoms. Toxicon, 2003, 41, 541-57.

31 WORLD HEALTH ORGANIZATION. WHO Expert Groups on Requirements for Biological Substances. Requirements for immune sera of animal origin. Geneva: WHO Tech. Report Series, 1969, 413, 45-59. [Appendix 2] 